\title{
Changes in the composition of maternal plasma, fetal plasma and fetal extraembryonic fluid during gestation in the rat
}

\author{
P. P. L. Tam and S. T. H. Chan \\ Department of Zoology, University of Hong Kong, Pokfulam Road, Hong Kong
}

\begin{abstract}
Summary. The changes in the biochemical composition of maternal plasma, fetal plasma and fetal extraembryonic fluid were studied in Wistar rats from Days $13 \frac{1}{2}$ to $21 \frac{1}{2}$ of gestation. During this period, there was an increase in maternal plasma volume and total blood volume. The total protein concentration decreased, but little change was observed in the protein pattern, total $\alpha$-amino nitrogen, urea nitrogen and sodium concentration. In fetal plasma, total protein concentration increased progressively with a prominent increase in albumin near term. The albumin:globulin ratio was lower than that in maternal plasma because of the presence of two $\alpha$-fetoproteins and four transferrins. The concentration of $\alpha$-amino nitrogen was higher than that in maternal plasma but the urea nitrogen level did not change significantly. The fetal extraembryonic fluid reflected the changes in composition of fetal plasma, especially in the protein pattern, and concentrations of $\alpha$-amino nitrogen and sodium. Total protein and urea nitrogen increased markedly in concentration near term but there was reduction in the fluid volume at this time.
\end{abstract}

\section{Introduction}

During embryonic development in the rat and mouse many rapid changes occur between Days $13 \frac{1}{2}$ and $22 \frac{1}{2}$ of gestation. The morphological changes of the embryos are well documented (Witschi, 1964; Rugh, 1968). The growth of the fetus follows a logarithmic relationship with gestational age (Stotsenburg, 1915; Renfree, Hensleigh \& McLaren, 1975) and is, in terms of weight, affected locally by the uterine environment and systemically by the maternal organism (Healy, McLaren \& Michie, 1960; Bruce \& Norman, 1975). A large part of the rodent conceptus consists of fetal fluids, represented by a number of fluid compartments (Adolph, 1967). The fetal plasma and extraembryonic fluid have been studied with respect to gestational age, placental weight and fetal weight in the mouse (McCafferty, 1955; Johnson, 1971; Renfree et al., 1975) and rat (Marsh, King \& Becker, 1963; Adolph, 1967). Changes in the protein composition of fetal plasma and extraembryonic fluid have also been studied from Day $11 \frac{1}{2}$ to term in mice (Gustine \& Zimmerman, 1972, 1973; Renfree \& McLaren, 1974; Renfree et al., 1975). However, similar studies in rats are scanty: plasma protein changes have been studied in fetuses after Day $17 \frac{1}{2}$ of gestation but not at earlier ages (Heim, 1961, 1962; Wise, Ballard \& Ezekiel, 1963), although Wirtschafter \& Williams (1957a) studied protein dynamics in the amniotic fluid from Days $14 \frac{1}{2}$ to $22 \frac{1}{2}$ by measuring the changes in protein patterns. The changes in protein patterns are believed to reflect the pathological state of the developing fetus (Wirtschafter \& Williams, 1957b) and the amino acid composition of the amniotic fluid (Wirtschafter, 1958) may also be important for diagnosis of aminoacidopathies (O'Neill, Morrow, Hammel, Auerbach \& Barnes, 1971).

The present study was undertaken to give a more complete picture than is at present available of the developmental changes in the protein patterns of the fetal plasma and the fetal extraembryonic fluid throughout the second half of gestation compared with those in the maternal plasma. The concentrations of amino acids, urea and sodium of the fluid compartments were also studied.

\section{Materials and Methods}

Animals. Uniparous females from a closed colony of Wistar albino rats (aged $4 \frac{1}{2}$ months and average body weight of about $200 \mathrm{~g}$ ) were caged with males of proven fertility. The day on which spermatozoa 
were present in the vaginal smear was taken as Day $\frac{1}{2}$ of gestation. Rats at Day $13 \frac{1}{2}-21 \frac{1}{2}$ of gestation were killed at random; animals with $<7$ normal fetuses were discarded.

Sample collection. The total body weight of each pregnant rat was recorded before killing and the combined weight of all the conceptuses of a litter was deducted to give the maternal body weight. The net gain in each of these two weights was then calculated from the body weight at Day $\frac{1}{2}$ of gestation. The rats were anaesthetized with ether and $0.5 \mathrm{ml} \mathrm{0.5 \%} \mathrm{T}-1824$ (Evans Blue: E. Merck, Darmstadt) in $0.9 \%$ heparinized $\mathrm{NaCl}$ was injected intravenously. After $15 \mathrm{~min}$, maternal blood was collected by exsanguination from the dorsal aorta and centrifuged at $1000 \mathrm{~g}\left(1 \mathrm{~h}\right.$ at $\left.4^{\circ} \mathrm{C}\right)$ and the plasma was frozen at $-20^{\circ} \mathrm{C}$ until analysis.

The uteri were excised and the conceptuses were dissected out with the placenta and membranes intact. The whole conceptus was weighed after blotting dry on Whatman filter paper. The sac fluid was collected by aspiration and samples from 3 fetuses of the same litter were pooled to give an adequate amount for biochemical analyses; any samples with possible signs of contamination with blood were discarded. The membranes were dissected free and the remaining fluid was removed by blotting. The fetus, placenta and associated membranes were reweighed; the difference between this weight and that of the whole conceptus represented the weight of extraembryonic fluid. The umbilical cord was dissected clear of attached membranes and was then cut for collection of fetal blood samples from the severed end into heparinized capillaries (DADE, Miami). Adequate samples for biochemical analysis were collected from fetuses at all the gestational ages studied. Plasma was obtained by centrifugation, then stored at $-20^{\circ} \mathrm{C}$ until analysis. The placenta and membranes were reweighed for calculation of fetal weights. Dry weights of the fetuses were determined after incubation in a hot-air oven at $140^{\circ} \mathrm{C}$ for 7 days.

Blood volume and plasma volume determination. The plasma and blood volumes were estimated from the T-1824 (Evans Blue) concentration colorimetrically and the haematocrit value (Loring, 1954). The correction factor for the disappearance rate of the dye from the circulation was determined by similar studies in 21 non-pregnant female rats (Dawson, Evans \& Whipple, 1920).

Biochemical analyses. The total protein concentrations in the maternal plasma, fetal plasma and extraembryonic fluid were measured with the Folin-Ciocalteau phenol reagent (Lowry, Rosebrough, Farr \& Randall, 1951). Electrophoresis of the samples was carried out in $7 \%$ polyacrylamide gel (Davis, 1964; Work \& Work, 1969) in a gel electrophoresis apparatus (Model 1270, ISCO, Nebraska) at $2-4{ }^{\circ} \mathrm{C}$. The protein bands were stained with $0.05 \%$ amido-black $10 \mathrm{~B}$ (Harleco, Philadelphia) in $7 \%$ acetic acid for $1 \mathrm{~h}$. The cleared gels were photographed and scanned in a recording electrophoresis densitometer (Densicord Photovolt, New York). The concentration of $\alpha$-amino nitrogen in the fluid samples was determined colorimetrically with the ninhydrin reagent as described by Matthews, Muir \& Baron (1964). The concentration of urea nitrogen in the fluid samples was determined by the urease method (Fawcett \& Scott, 1960) with modification (Chaney \& Marbach, 1962). Sodium concentrations were measured in an atomic absorption spectrophotometer (Model 290, Perkin-Elmer, Norwalk) following the proscribed procedure (Perkin-Elmer, 1968).

\section{Results}

\section{Weight changes}

The increase in body weight of the pregnant rats was mainly accounted for by the rapid growth of the conceptuses after Day $16 \frac{1}{2}$ while the maternal body weight remained unchanged (Table 1).

The relative proportion of dry matter in the fetus decreased from 16\% (Day $13 \frac{1}{2}$ ) to $7 \%$ (Day $16 \frac{1}{2}$ ), indicating that the gain in wet weight of the fetus in this period was mainly due to fluid incorporation. The wet weight of the placenta progressively increased towards term but its relative proportion in the whole conceptus and its weight relative to that of the fetus (wet weight) decreased (Table 1). The extraembryonic fluid constituted the major portion of the whole conceptus at Day $13 \frac{1}{2}$; this fluid accumulated and reached peak weight at Day $19 \frac{1}{2}$, then diminished rapidly until little remained at term (Table 1). 

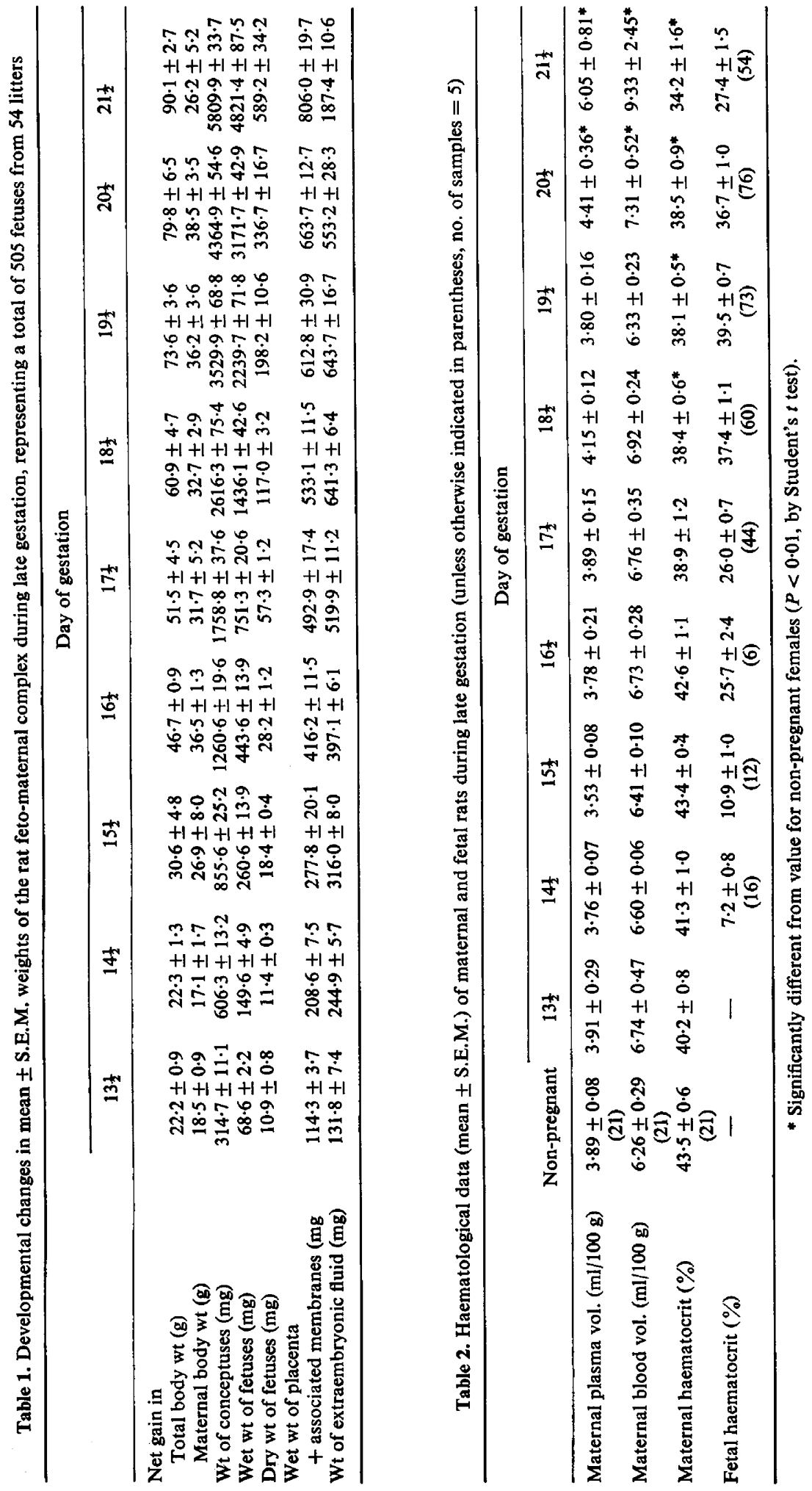


\section{Blood volume}

The blood and plasma volumes did not vary significantly from the values estimated for nonpregnant females before Day $19 \frac{1}{2}$, when they began to increase. The fetal haematocrit value progressively increased before Day $19 \frac{1}{2}$ but dropped near term $(P<0.01)$ when there was haemodilution of the maternal blood (Table 2).

\section{Total protein and protein pattern}

The total protein concentration in the maternal plasma decreased progressively during the period studied and was significantly $(P<0.01)$ lower than that in non-pregnant females (Table 3$)$. The concentration in fetal plasma increased from about $20 \%$ that in maternal plasma before Day $17 \frac{1}{2}$ to about $50 \%$ near term. Concentrations in the extraembryonic fluid increased only slightly until the last 2 days of pregnancy.

On the electrophoresis gels of maternal plasma, about 19 bands were identified by their mobility (M) relative to albumin (e.g. at Day $20 \frac{1}{2}$, Text-fig. 1a). Bands with $M$ values of $0.90-0.65$ were grouped as $\alpha$-globulins, of $0.65-0.30$ as $\beta$-globulins and those of $<0.30$ as $\gamma$-globulins. Patterns of proteins in T-1824-injected maternal plasma were the same as those without the dye. The patterns in the fetal plasma (Text-fig. 1b) mostly resembled those of the maternal plasma, but there were two $\alpha$-fetoproteins, four transferrins $\left(T_{1}, T_{2}, T_{3}, T_{4}\right)$ and fewer bands in the $\gamma$-globulins region. The extraembryonic fluid (Text-fig. 1c), containing albumin, two $\alpha$-fetoproteins, 4 transferrins and 1-2 bands of $\gamma$-globulins, resembled the fetal plasma more than the maternal plasma.

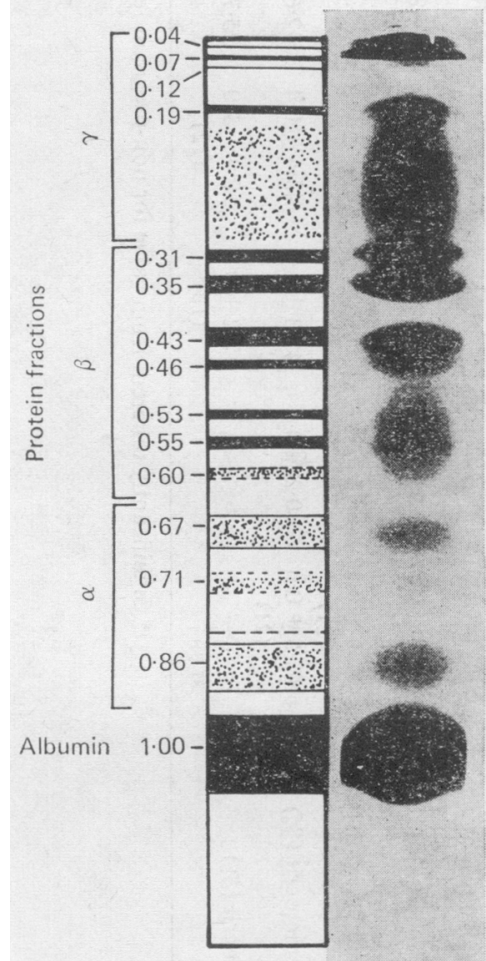

(a)
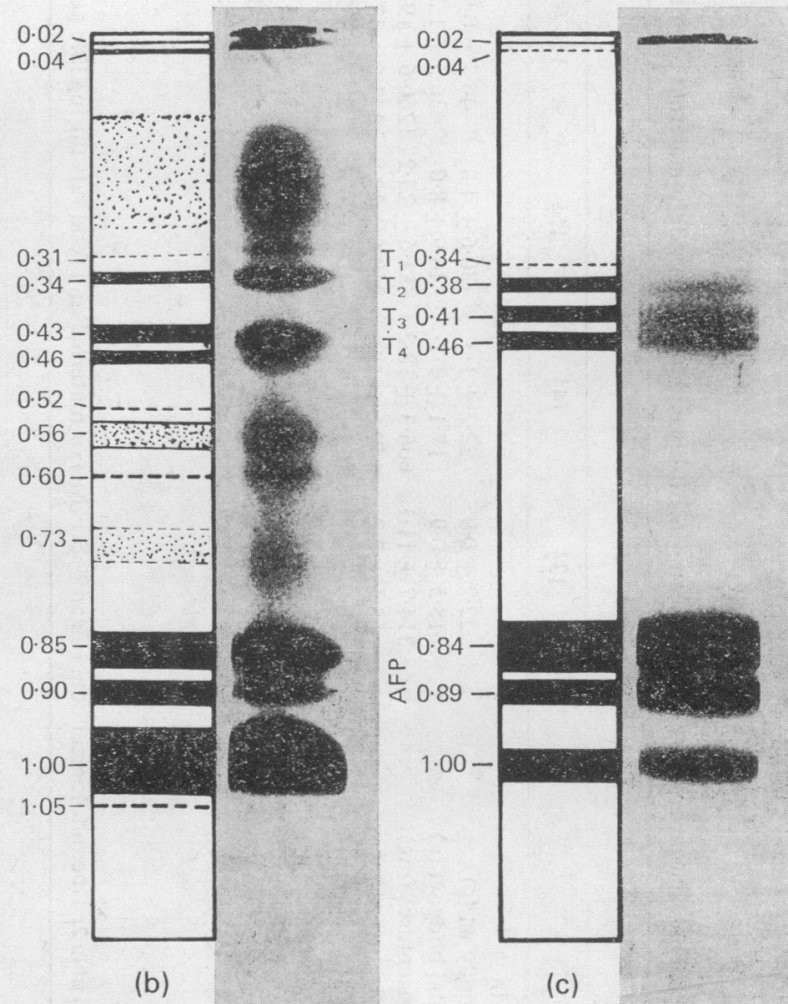

Text-fig. 1. Electrophorograms of (a) maternal plasma, (b) fetal plasma and (c) fetal extraembryonic fluid of rats at Day $20 \frac{1}{2}$ of gestation. $T_{1}, T_{2}, T_{3}, T_{4}$ denote transferrin bands; AFP denotes $\alpha$-fetoproteins. 


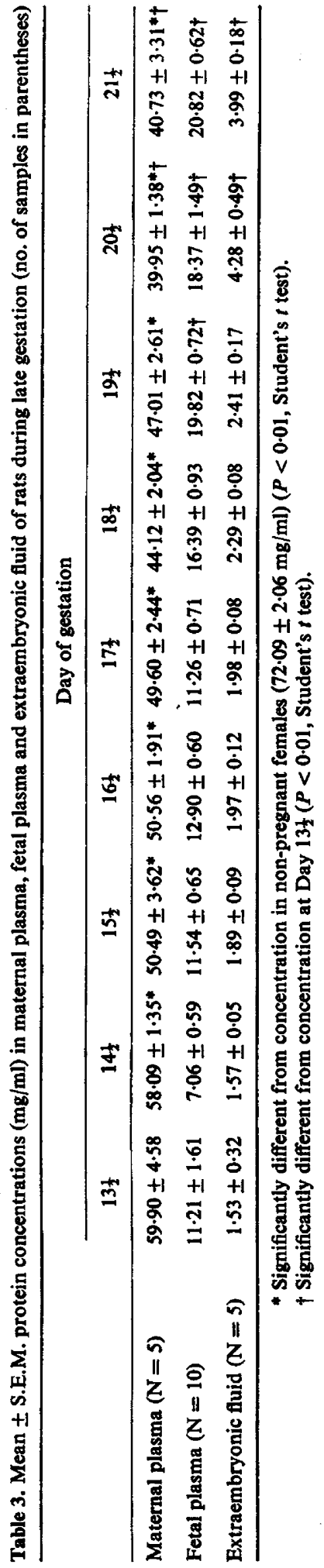


(a)
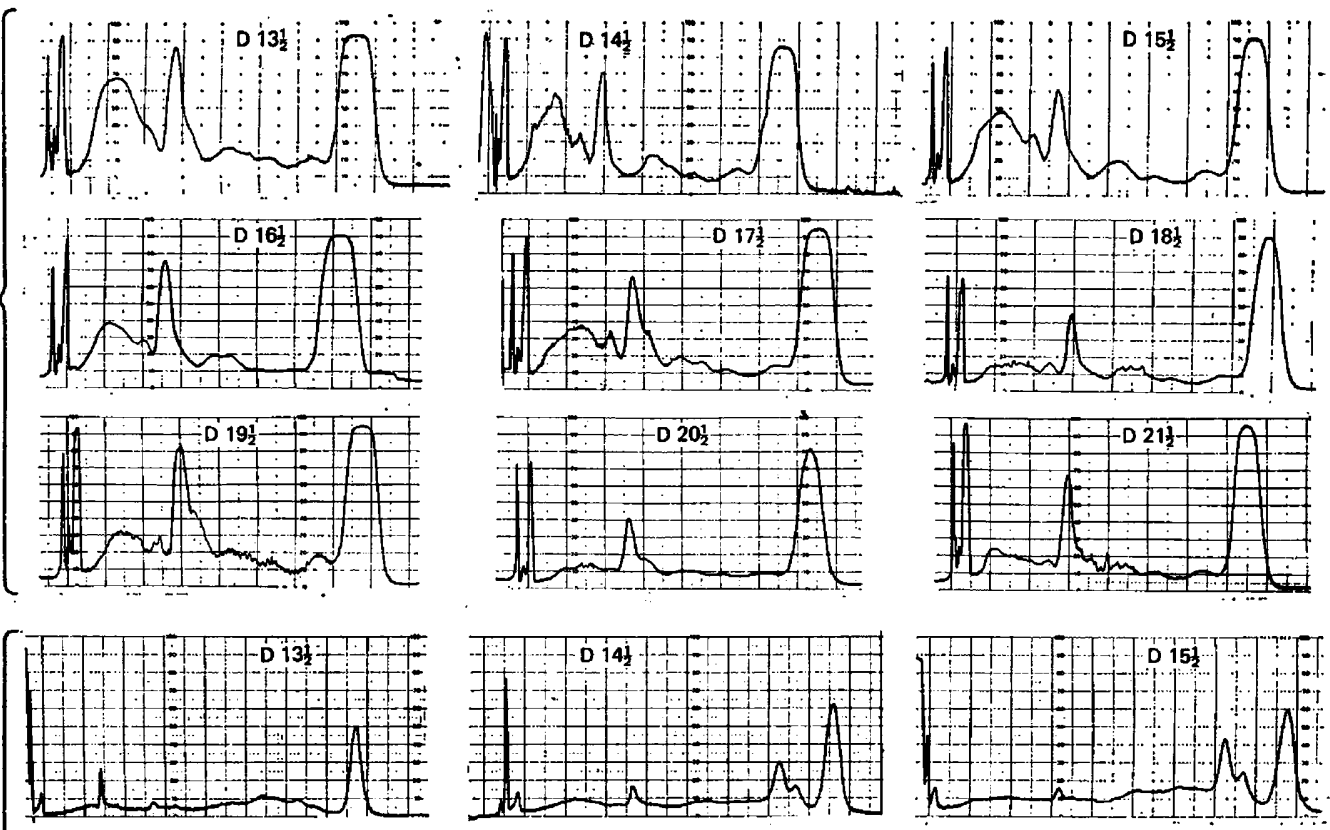

(b)
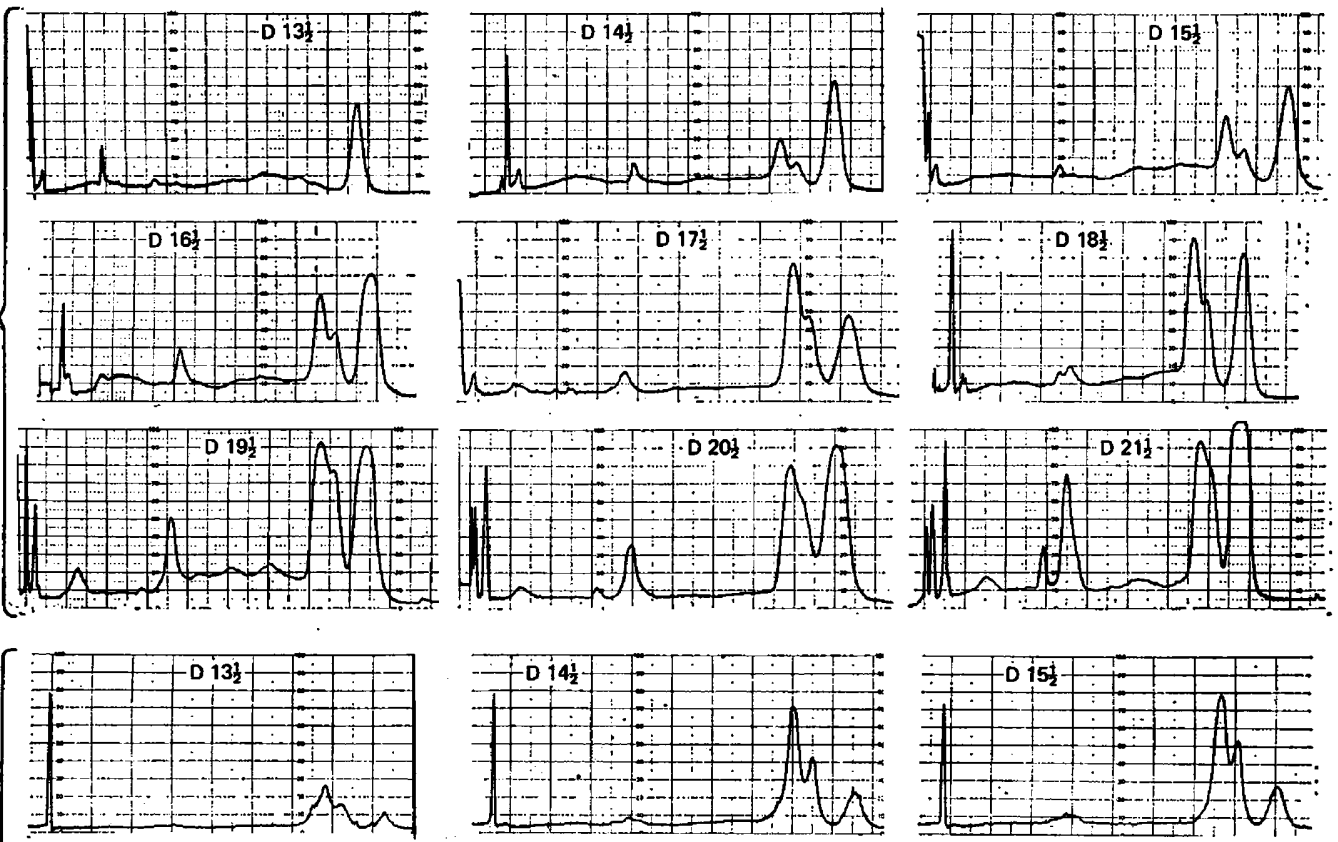

(c)
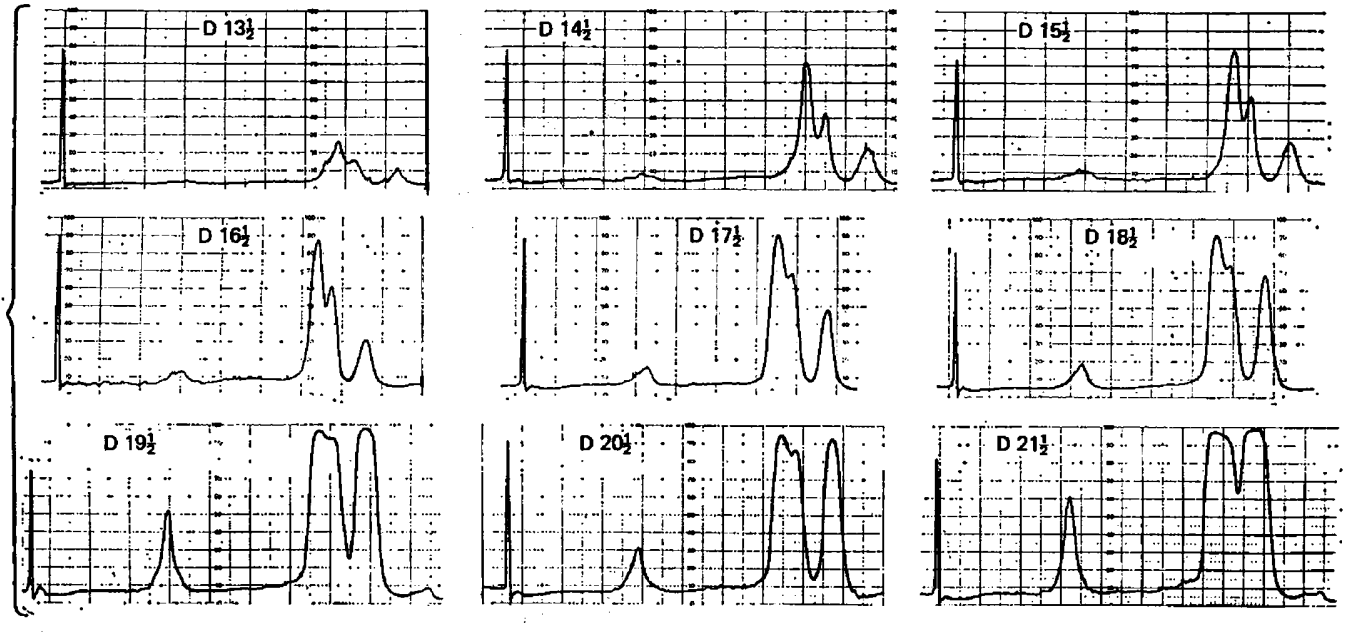

Text-fig. 2. Electrophorograms of (a) maternal plasma, (b) fetal plasma, and (c) fetal extraembryonic fluid of

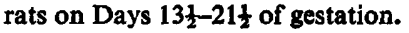




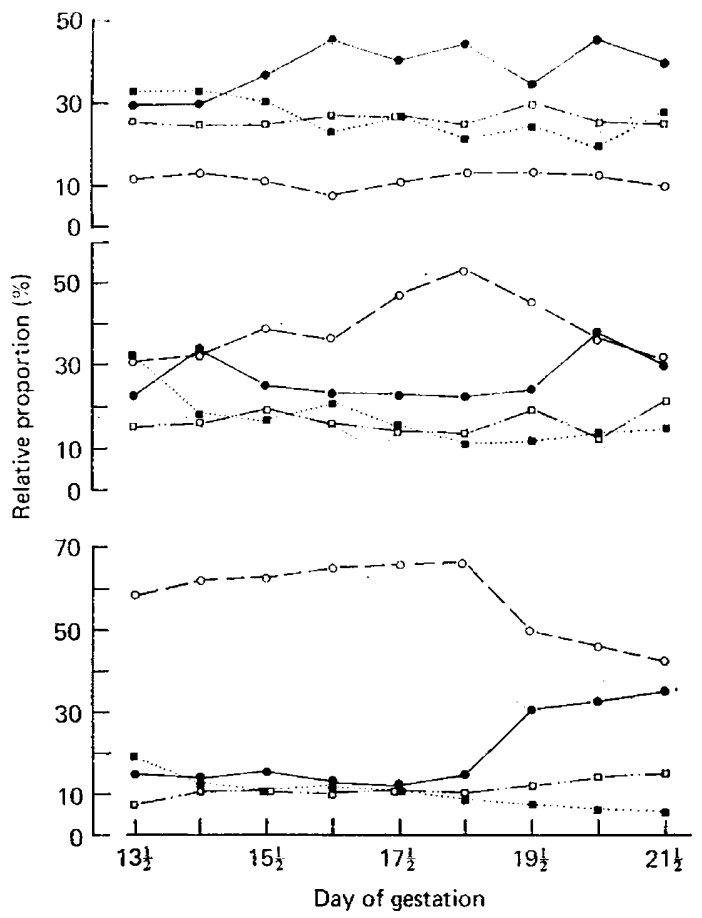

Text-fig. 3. The electrophoretic distribution of protein fractions in (a) maternal plasma, (b) fetal plasma and (c) fetal extraembryonic fluid. $\bullet$, Albumin; $0, \alpha$-globulins; $\square, \beta$-globulins; $\square, \gamma$-globulins.

There was little change during pregnancy in the protein patterns of maternal plasma (Text-fig. 2a). Albumin always constituted the major fraction and $\alpha$-globulin was the smallest fraction (Text-fig. 3a). The albumin: globulin ratio increased slightly from Day $14 \frac{1}{2}$ onwards (Table 4). Unlike those of the maternal plasma, the protein patterns of fetal plasma showed a progressive change (Text-fig. $2 b$ ): the $\alpha$-globulins (especially the two $\alpha$-fetoproteins) were prominent throughout (Text-fig. $3 b$ ). The $\alpha$ fetoproteins always existed as two distinct bands and their individual mobility indices slightly increased towards term (Text-fig. 2b). The increase in the staining intensity of the faster moving component implied a building up of this protein as gestation proceeded. The 4 transferrins were identified by their electrophoretic mobilities; the slowly migrating $T_{1}$ and $T_{2}$ appeared in the earliest samples while the faster $T_{3}$ and $T_{4}$ appeared on Days $16 \frac{1}{2}$ and $17 \frac{1}{2}$, and became the main components near term. There was also a progressive increase in $\gamma$-globulin bands and their intensity (Text-fig. $2 b$ ). The increase in total protein concentration from Day $18 \frac{1}{2}$ onwards was mainly contributed by albumin while the $\alpha$-globulins decreased (Text-fig. $3 b$ ).

The protein changes in the extraembryonic fluid reflected those in the fetal plasma (Text-figs $2 \mathrm{c}$ and 3c). The albumin: globulin ratio was the lowest of the three fluid compartments (Table 4). A marked change in the relative proportion of albumin accounted for most of the increase in total

Table 4. The albumin: globulin ratio of maternal plasma, fetal plasma and extraembryonic fluid of rats in late gestation

\begin{tabular}{lccccccccc}
\hline & \multicolumn{1}{c}{ Day of gestation } \\
\cline { 2 - 9 } & $13 \frac{1}{2}$ & $14 \frac{1}{2}$ & $15 \frac{1}{2}$ & $16 \frac{1}{2}$ & $17 \frac{1}{2}$ & $18 \frac{1}{2}$ & $19 \frac{1}{2}$ & $20 \frac{1}{2}$ & $21 \frac{1}{2}$ \\
\hline Maternal plasma (\%) & $41 \cdot 7$ & $41 \cdot 5$ & $52 \cdot 7$ & $75 \cdot 6$ & $58 \cdot 1$ & $78 \cdot 6$ & $50 \cdot 9$ & $82 \cdot 0$ & $64 \cdot 2$ \\
Fetal plasma (\%) & 28.6 & $49 \cdot 9$ & $33 \cdot 6$ & $38 \cdot 7$ & $30 \cdot 4$ & $29 \cdot 1$ & $31 \cdot 4$ & $59 \cdot 0$ & $42 \cdot 2$ \\
Extraembryonic fluid (\%) & $17 \cdot 3$ & $16 \cdot 2$ & $18 \cdot 4$ & $14 \cdot 7$ & $13 \cdot 8$ & $18 \cdot 0$ & $38 \cdot 1$ & 43.9 & $54 \cdot 4$ \\
\hline
\end{tabular}


protein near term (Text-fig. 3c). The two $\alpha$-fetoproteins were always the major protein fractions and there was a gradual increase in the electrophoretic mobility and the band intensity of both components, especially the faster one (Text-fig. 2c). Of the 4 transferrin bands, $T_{1}, T_{2}$, and $T_{3}$ were noticeable on Day $14 \frac{1}{2}$ with $T_{2}$ as the major band; Band $T_{3}$ gradually intensified from Day $15 \frac{1}{2}$ onwards and became the most prominent band on Day $21 \frac{1}{2} ; T_{1}$ and $T_{2}$ gradually diminished by Day $20 \frac{1}{2}$; and $T_{4}$ appeared after Day $19 \frac{1}{2}$ (Text-fig. 2c).

\section{Amino acids}

There was no significant variation in the amino acid concentrations in the maternal plasma despite an increase in the plasma volume near term (Table 5). Concentrations in the fetal plasma and extraembryonic fluid were greater than those in maternal plasma; both increased at the end of gestation, but the temporal pattern and the magnitude of the earlier fluctuations were not similar (Table 5).

\section{Urea nitrogen}

The concentration of urea was lower in the fetal plasma than in the maternal plasma, but in both compartments it remained fairly consistent throughout this period of gestation (Table 6). The changes of urea concentrations in extraembryonic fluid were similar to those of protein (see Table 3) and as the fluid volume decreased near term, the urea concentration increased.

\section{Sodium}

The sodium concentration in the maternal plasma was maintained within a range of $110-140$ mequiv./l and did not significantly differ from that in non-pregnant animals, even when the plasma volume increased (Table 7). There was a peak of sodium concentration at Day $18 \frac{1}{2}$ in the fetal plasma and a corresponding rise was observed in extraembryonic fluid (Table 7). The concentration in the extraembryonic fluid remained otherwise unchanged despite the marked change in fluid volume.

\section{Discussion}

In most mammals, the extraembryonic fluid accumulates early in gestation and later diminishes (Adolph, 1967). In the present study of rats, as in mice (Johnson, 1971; Renfree et al., 1975), the weight of this fluid increased until Day $19 \frac{1}{2}$, then diminished rapidly until little remained at term. This fluid volume in the rat is largely regulated by the inner visceral yolk sac, the outer parietal yolk sac and Reichert's membrane (Payne \& Deuchar, 1972). The latter two membranes break down on Day $16 \frac{1}{2}$, and the remaining visceral yolk sac also disappears near term, leaving only the part investing the surface of the placenta (Jollie, 1968; Brambell, 1970). The change in fluid volume near term may therefore be due to the decline of the regulatory function of one or both of these membranes, or to consumption by the fetus (Marsh et al., 1963; Renfree et al., 1975), because our findings indicated a concomitant haemodilution of the fetal blood.

The changes in biochemical composition of the fetal fluid had direct correlation with the stage of fetal development. The continuous drop in total protein concentration in maternal plasma during gestation was partly due to the increase in blood volume, especially near term, but the changes in the relative proportions of the maternal plasma proteins indicate a changing protein metabolism to meet the demands of gestation. Sell (1973), Masseyeff, Gilli, Krebs, Calluaud \& Bonet (1975) and Lai, Forrester, Hancock, Hay \& Lorscheider (1976) found, by radioimmunoassay, an increase in $\alpha$ fetoproteins in pregnant rat serum. We detected these proteins by polyacrylamide gel electrophoresis in fetal plasma but not in maternal plasma, probably because of the limited sensitivity of the technique and the low level of these proteins in the maternal plasma. The albumin:globulin ratio in rat fetal plasma was lower than that of maternal plasma, mainly because of the presence of two $\alpha$ fetoproteins and four transferrins. A progressive increase in the concentration of individual electrophoretic components has been demonstrated in serum from fetal rats in late pregnancy (Heim, 1961) and Grabar \& Courcon (1958) indicated a sequential acquisition of the proteins characteristic of adult 

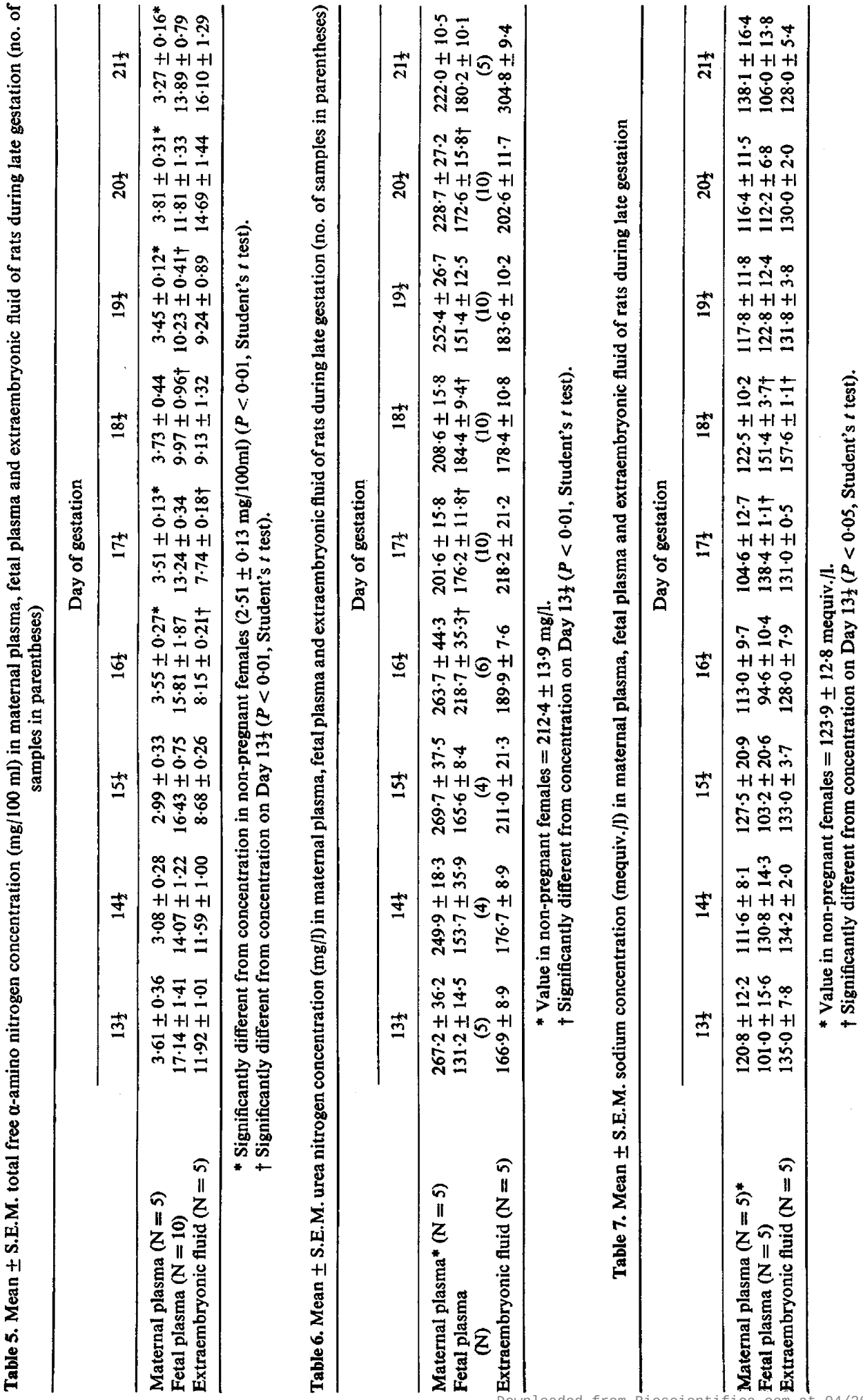
serum in the developing fetus. We also found an increase in the concentration of the fast moving glycoproteins after Day $16 \frac{1}{2}$ and in the electrophoretic mobility of $\alpha$-fetoproteins and transferrins towards term. In mice and rats, the faster components, with more sialic acid moieties in their molecules (Gustine \& Zimmerman, 1973; Watanabe, Taketa \& Kosaka, 1975), dominated the protein pattern towards the end of gestation (Renfree et al., 1975) and this shift from the slower to the faster components represents a regulation of glycoprotein biosynthesis at the level of carbohydrate attachment (Gustine \& Zimmerman, 1973).

It is known that albumin and other globulins are synthesized by the fetal rat near term (Kelleher, Kenyon \& Villee, 1963), and this may account for the increase found in this study. However, albumin and other proteins may be derived from the maternal pool near term when there is a change in the membrane barrier between the maternal blood and fetal blood (Jollie, 1968). Lambson (1966) suggested that the yolk sac endoderm may, in late pregnancy, release stored proteins to the vitelline circulation or directly to the cavity fluid, though the nature of the protein was undefined.

As in other mammals (Young \& Prenton, 1969; Young \& Hill, 1973; Baetz, Hubbert \& Graham, 1975 ), the concentration of total $\alpha$-amino acids was highest in the fetal plasma, indicating an enhanced protein turnover rate in the fetus. Since the free amino acids need to be transferred across the placental membranes, those in the maternal plasma are presumably moved against a concentration gradient by active processes related to the fetal metabolism (Young \& Hill, 1973). The increased urea level in the fetal plasma near term is probably related to the increased nitrogen metabolism in the then functional fetal liver. Urea levels in the extraembryonic fluid reflect the excretion of this metabolite from the fetus (Battaglia \& Meschia, 1973).

The present study of the biochemical composition of maternal and fetal fluids has demonstrated distinct patterns of change which will be useful as a baseline for future studies on the maturation of the fetal organs and feto-maternal relationships.

This work was supported by a research grant from the University of Hong Kong. We thank Dr R. G. Edwards for reading the manuscript, Dr D. K. O. Chan for his advice on atomic absorption spectrophotometry and Professor B. Lofts for his interest and encouragement.

\section{References}

ADOLPH, E.F. (1967) Ontogeny of volume regulations in embryonic extracellular fluids. $Q$. Rev. Biol. 42, 1-39.

Baetz, A.L., Hubbert, W.T. \& Graham, C.K. (1975) Developmental changes of amino acids in bovine fetal fluids with gestational age and the interrelationships between the amino acid concentrations in the fluid compartments. J. Reprod. Fert. 44, 437-444.

Battaglia, F.G. \& Meschia, G. (1973) Fetal metabolism and substrate utilization. In Fetal and Neonatal Physiology, Proc. Sir Joseph Barcroft Centenary Symp., pp. 382-397. Eds R. S. Comline, K. W. Cross, G. S. Dawes \& P. W. Nathanielsz. Cambridge University Press.

Brambell, F.W.R. (1970) The Transmission of Passive Immunity from Mother to Young. North-Holland, Amsterdam, London.

BruCE, N.W. \& NormaN, N. (1975) Influence of sexual dimorphism on foetal and placental weights in the rat. Nature, Lond. 257, 62-63.

Chaney, A.L. \& Marbach, E.P. (1962) Modified reagents for determination of urea and ammonia. Clin. Chem. 8, 130-132.
Davis, B.J. (1964) Disc electrophoresis II. Method and application to human serum proteins. Ann. N.Y. Acad. Sci. 121, 404-427.

Dawson, A.B., Evans, H.M. \& Whipple, G.H. (1920) Blood volume studies. III. Behaviour of large series of dyes introduced into the circulating blood. Am. J. Physiol. 51, 232-256.

FAWCETT, J.K. \& SCOTT, J.E. (1960) A rapid and precise method for the determination of urea. J. clin. Path. 13, 156-159.

Grabar, P. \& Courcon, J. (1958) Immunoelectrophoresis of horse, rabbit, rat and mouse sera. Bull. Soc. Chim. biol. Paris 40, 1993-2003.

Gustine, D.L. \& Zimmerman, E.F. (1972) Amniotic fluid proteins: evidence for the presence of fetal plasma glycoproteins in mouse amniotic fluid. $\mathrm{Am}$. J. Obstet. Gynec. 114, 553-560.

Gustine, D.L. \& Zimmerman, E.F. (1973) Developmental changes in microheterogeneity of foetal plasma glycoproteins of mice. Biochem. J. 132, 541551.

Healy, M.J.R., Mclaren, A. \& Michie, D. (1960) Foetal growth in the mouse. Proc. R. Soc. B 153, 367-379. 
HeIM, W.G. (1961) The serum proteins of rat during development. J. Embryol. exp. Morph. 9, 52-59.

Herm, W.G. (1962) A rat serum protein related to reproduction, tissue synthesis and lactation. Nature, Lond. 193, 491.

Jollie, W.P. (1968) Changes in the fine structure of the parietal yolk sac of the rat placenta with increasing gestational age. Am. J. Anat. 122, 513-520.

JoHnson, D.R. (1971) Genes and genotypes affecting embryonic fluid relations in the mouse. Genet. Res., Camb. 18, 71-79.

Kelleher, P.C., Kenyon, C.D. \& Villee, C.A. (1963) Serum protein synthesis by the fetal rat. Science, $N$. $Y$. 139, 839-840.

LaI, P.C.W., Forrester, P.I., Hancock, R.L., Hay, D.M. \& LoRscheider, F.L. (1976) Rat $\alpha$-fetoprotein: isolation, radioimmunoassay and fetomaternal distribution during pregnancy. J. Reprod. Fert. 48, 1-8.

LAMBSON, R.O. (1966) An electron microscopic visualization of transport across rat visceral yolk sac. $A m . J$. Anat. 118, 21-52.

LoRING, W.E. (1954) A rapid, simplified method for serial blood volume determinations in the rat. Proc. Soc. exp. Biol. Med. 85, 350-351.

Lowry, O.H., Rosebrough, N.J., FARr, A.L. \& RANDALL, R.J. (1951) Protein measurement with the Folin phenol reagent. J. biol. Chem. 193, 265-275.

MARSH, R.H., KING, J.E. \& BeCKER, R.F. (1963) Volume and viscosity of amniotic fluid of the rat and guinea pig at near term. Am. J. Obstet. Gynec. 85, 487-492.

Masseyeff, R., Gilli, J. Krebs, B., Calluaud, A. \& BONET, C. (1975) Evolution of $\alpha$-fetoprotein serum levels throughout life in humans and rats, and during pregnancy in the rat. Ann. N.Y. Acad. Sci. 259, 1728.

Matthews, D.M., Muir, G.G. \& Baron, D.N. (1964) Estimation of $\alpha$-amino nitrogen in plasma and urine by the colorimetric ninhydrin reaction. J. clin. Path. 17, 150-153.

MCCAFferty, R.E. (1955) A physiological study of the amniotic fluid of the mouse. I. Volume and weight changes of the amniotic fluid compared with the weights of fetus and placenta during gestation. Anat. Rec. 123, 521-530.

O'Neill, R.T., Morrow, G., III, Hammel, D., AUerBACH, V.H. \& BARNES, L.A. (1971) Diagnostic significance of amniotic fluid amino acids. Obstet. Gynec., N.Y. 37, 550-554.

Payne, G.S. \& Deuchar, E.M. (1972) An in vitro study of the functions of embryonic membranes in rats. $J$. Embryol. exp. Morph. 27, 533-542.
Perkin-Elmer (1968) Standard condition for sodium and potassium in blood serum. In Analytical Methods for Atomic Absorption Spectrophotometry. Perkin-Elmer, Norwalk, Connecticut.

Renfree, M.B. \& MCLAREN, A. (1974) Foetal origin of transferrin in mouse amniotic fluid. Nature, Lond. 252, 159-161.

Renfree, M.B., Hensleigh, H.C. \& Mclaren, A. (1975) Developmental changes in the composition and amount of mouse foetal fluids. J. Embryol. exp. Morph. 33, 435-446.

Rugh, R. (1968) The Mouse, its Reproduction and Development. Burgess, Minneapolis.

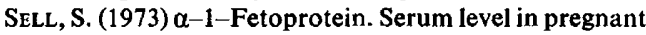
rats. J. natn. Cancer Inst. 51, 689-701.

Stotsenburg, J.M. (1915) The growth of the fetus of the albino rat from the thirteenth to the twenty-second day of gestation. Anat. Rec. 9, 667-682.

Watanabe, A., TAketa, K. \& KosakA, K. (1975) Microheterogeneity of rat $\alpha$-fetoprotein. Ann. N.Y. Acad. Sci. 259, 95-108.

WIRTSCHAFTER, Z.T. (1958) The dynamics of free amino acids in the amniotic fluid of rats. $A m . J$. Obstet. Gynec. 75, 718-723.

WirtschafTeR, Z.T. \& Williams, D.W. (1957a) Dynamics of the amniotic fluid as measured by the changes in protein patterns. Am. J. Obstet. Gynec. 74, 309-313.

WIRTSCHAFTER, Z.T. \& WILliams, D.W. (1957b) The dynamics of protein changes in amniotic fluid of normal and abnormal rat embryos. Am. J. Obstet. Gynec. 74, 1023-1028.

Wise, R.W., Ballard, F.T. \& Ezekiel, E. (1963) Developmental changes in the plasma protein pattern of the rat. Comp. Biochem. Physiol. 9, 23-30.

WITSCHI, E. (1964) Development:rat; Growth; VII. Prenatal development. In Biological Handbooks, pp. 304-314. Eds P. L. Altman \& D. S. Dittmer. Fedn Am. Socs. exp. Biol., Washington, D.C.

WORK, T.S. \& WoRK, E. (Eds) (1969) Laboratory Techniques in Biochemistry and Molecular Biology. Part. I. Electrophoresis of proteins in Polyacrylamide and Starch gels. North-Holland, Amsterdam.

Young, M. \& Prenton, M.A. (1969) Maternal and fetal plasma amino acids concentration during gestation and in retarded fetal growth. J. Obstet. Gynaec. Br. Commonw. 76, 333-344.

Young, M. \& Hrll, P.M.M. (1973) Free amino acid transfer across the placental membrane. In Fetal and Neonatal Physiology. Proc. Sir Joseph Barcroft Centenary Symp. pp. 329-338. Eds R. S. Comline, K. W. Cross, G. S. Dawes \& P. W. Nathanielsz. Cambridge University Press. 